\title{
Turner's syndrome mosaicism in girls with neurodevelopmental disorders: a cohort study and hypothesis
}

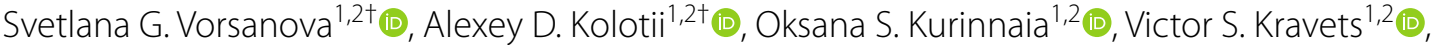 \\ Irina A. Demidova ${ }^{1,2}$, Ilya V. Soloviev ${ }^{2}$, Yuri B. Yurov ${ }^{1,2}$ (D) and Ivan Y. Iourov ${ }^{1,2,3^{*}}$ (D)
}

\begin{abstract}
Background: Turner's syndrome is associated with either monosomy or a wide spectrum of structural rearrangements of chromosome X. Despite the interest in studying (somatic) chromosomal mosaicism, Turner's syndrome mosaicism (TSM) remains to be fully described. This is especially true for the analysis of TSM in clinical cohorts (e.g. cohorts of individuals with neurodevelopmental disorders). Here, we present the results of studying TSM in a large cohort of girls with neurodevelopmental disorders and a hypothesis highlighting the diagnostic and prognostic value.

Results: Turner's syndrome-associated karyotypes were revealed in 111 (2.8\%) of 4021 girls. Regular Turner's syndrome-associated karyotypes were detected in 35 girls (0.9\%). TSM was uncovered in 76 girls (1.9\%). TSM manifested as mosaic aneuploidy (45,X/46,XX; 45,X/47,XXX/46,XX; 45,X/47,XXX) affected 47 girls (1.2\%). Supernumerary marker chromosomes derived from chromosome $X$ have been identified in 11 girls with TSM (0.3\%). Isochromosomes $\mathrm{XX(q)}$ was found in 12 cases (0.3\%); one case was non-mosaic. TSM associated with ring chromosomes was revealed in 5 girls (0.1\%).

Conclusion: The present cohort study provides data on the involvement of TSM in neurodevelopmental disorders among females. Thus, TSM may be an element of pathogenic cascades in brain diseases (i.e. neurodegenerative and psychiatric disorders). Our data allowed us to propose a hypothesis concerning ontogenetic variability of TSM levels. Accordingly, it appears that molecular cytogenetic monitoring of TSM, which is a likely risk factor/biomarker for adultonset multifactorial diseases, is required.
\end{abstract}

Keywords: Aneuploidy, Chromosome X, Fluorescence in situ hybridization (FISH), Molecular cytogenetics, Phenotype, Somatic mosaicism, Turner's syndrome

\section{Background}

Since the beginning of the last century, Turner's syndrome has been systematically described in clinical and cytogenetic aspects [1-3]; the syndrome is occasionally

\footnotetext{
*Correspondence: ivan.iourov@gmail.com

†'Svetlana G. Vorsanova and Alexey D. Kolotii have contributed equally to this work

2 Yurov's Laboratory of Molecular Genetics and Cytogenomics of the Brain, Mental Health Research Center, Moscow, Russia 115522

Full list of author information is available at the end of the article
}

designated as Shereshevsky-Turner syndrome in Russia and as Ullrich-Turner syndrome in Germany [1,3]. This chromosomal disorder may result from monosomy of chromosome $\mathrm{X}$ (loss of whole chromosome $\mathrm{X}$ ), mosaicism for $\mathrm{X}$ chromosome aneuploidy/loss and $\mathrm{X}$ chromosome aberrations, or structural rearrangements of $\mathrm{X}$ chromosome leading to a loss of syndrome-specific X chromosome loci $[4,5]$. It is generally accepted that $45 \%$ of Turner's syndrome cases are associated with non-mosaic monosomy of chromosome X. The remainder is associated with mosaic aberrations of original author(s) and the source, provide a link to the Creative Commons licence, and indicate if changes were made. The images or other third party material in this article are included in the article's Creative Commons licence, unless indicated otherwise in a credit line to the material. If material is not included in the article's Creative Commons licence and your intended use is not permitted by statutory regulation or exceeds the permitted use, you will need to obtain permission directly from the copyright holder. To view a copy of this licence, visit http://creativecommons.org/licenses/by/4.0/. The Creative Commons Public Domain Dedication waiver (http://creativeco mmons.org/publicdomain/zero/1.0/) applies to the data made available in this article, unless otherwise stated in a credit line to the data. 
chromosome X (e.g. monosomy/disomy; monosomy/ trisomy; monosomy/marker chromosome; monosomy/ structural rearrangement(s); monosomy/isochromosome; monosomy/ring chromosome) in $20-35 \%$ of cases and with $\mathrm{X}$ chromosome rearrangements (isochromosome Xq, deletions of Xp and other exclusive rearrangements) in $10-35 \%$ of cases [5, 6]. Furthermore, mosaic $\mathrm{X}$ chromosome loss is repeatedly shown to be a possible element of pathogenic cascades in a variety of multifactorial diseases including brain (neurodevelopmental) disorders [7]. According to the available literature, there have been significant efforts for uncovering genotypephenotype correlations in cohorts of females suffering from Turner's syndrome with special attention to mosaic cases $[6,8-11]$. However, Turner's syndrome mosaicism (TSM) is usually ignored as a target in molecular (cyto) genetic analyses of neurodevelopmental (neurobehavioral) cohorts. Thus, TSM has been occasionally addressed in the context of neurodevelopmental disorders and molecular cytogenetic analysis of TSM in related clinical cohorts.

Here, we describe the study of TSM in a large cohort of girls with neurodevelopmental disorders and congenital anomalies by molecular cytogenetic techniques. Karyotypic and clinical data have been taken into account for understanding possible phenotypic outcomes of TSM. A hypothesis concerning ontogenetic instability of TSM suggesting diagnostic and prognostic significance of the analysis has been accordingly proposed.

\section{Materials and methods \\ Patients}

The cohort of girls with neurodevelopmental disorders (intellectual disability, autism and/or epilepsy) and congenital anomalies included 4021 individuals. The ages ranged between 4 months and 18 years. Molecular cytogenetic and molecular studies of the cohort were approved by the Ethics Committee of the Veltischev Research and Clinical Institute for Pediatrics of the Pirogov Russian National Research Medical University, Ministry of Health of Russian Federation, Moscow. Written informed consent was obtained from the parents of the patients.

\section{Cytogenetic analysis}

Karyotyping by G- and C-banding was performed for all the girls from the cohort as detailed previously [12-14]. G-banding resolution was no less than 550 bands according to ISCN 2016 [15].

\section{FISH}

Somatic chromosomal mosaicism was evaluated using fluorescence in situ hybridization (FISH) with chromosome-enumeration and site-specific DNA probes. X-chromosome-specific probe (DXZ1) was used in all the cases suggested to be affected by X chromosome monosomy (mosaic and non-mosaic). Sitespecific DNA probes for the short arm and long arm of chromosome $\mathrm{X}$ (structural rearrangements) and chromosome-enumeration DNA probes for autosomes and chromosome Y (marker chromosomes and controlling during analysis of low-level mosaicism for rearrangements of chromosome $\mathrm{X}$ ) were applied when needed. DNA probe labeling, in situ hybridization and detection was performed according to previously described protocols $[16,17]$. Interphase FISH analysis was performed as repeatedly described in details [18-21]. Quantitative FISH was applied to metaphase plates and/or interphase nuclei for increasing the efficiency of scoring. The details of the analysis were previously described [19].

\section{SNP-array}

SNP-array-analysis (molecular karyotyping) using CytoScan HD Arrays (Affymetrix, Santa Clara, CA, USA) consisting of about 2.7 million markers was performed as described earlier $[22,23]$. Data were visualized using the Affymetrix ChAS (Chromosome Analysis Suite) software CytoScan ${ }^{\circledR}$ HD Array Version 4.1.0.90/r29400 (reference sequence-GRCh37/hg19).

\section{Results}

Cytogenetic and molecular cytogenetic analyses has identified Turner's syndrome-associated karyotypes in $111(2.8 \%)$ out of 4021 girls with neurodevelopmental disorders and congenital anomalies. Regular (nonmosaic) Turner's syndrome-associated karyotypes have been detected in 35 girls $(0.9 \%$ or $31.5 \%$ out of the whole group or girls with Turner's syndrome-associated karyotypes, respectively). Twenty seven individuals (24.3\%) have exhibited regular 45,X karyotypes (Fig. 1), whereas 8 patients (7.2\%) have demonstrated structural rearrangements. TSM has been uncovered in 76 girls $(1.9 \%$ or $68.5 \%$ out of the whole group or out of girls with Turner's syndrome-associated karyotypes, respectively).

Interphase FISH (Fig. 2) has confirmed all the mosaic cases of TSM. TSM manifested as mosaic aneuploidy (i.e. $45, \mathrm{X} / 46, \mathrm{XX} ; 45, \mathrm{X} / 47, \mathrm{XXX} / 46, \mathrm{XX}$; or $45, \mathrm{X} / 47, \mathrm{XXX}$ ) has affected 47 girls (1.2\%). Mosaicism levels varied from 5 to $90 \%$. The remaining cases have been associated with mosaic marker chromosomes, isochromosomes and ring chromosomes.

Supernumerary marker chromosomes have been identified in 11 girls with TSM $(0.3 \%)$. Table 1 provides an overview of TSM cases with marker chromosomes. It is noteworthy that all the marker chromosomes have derived from chromosome $\mathrm{X}$ as uncovered by FISH with 

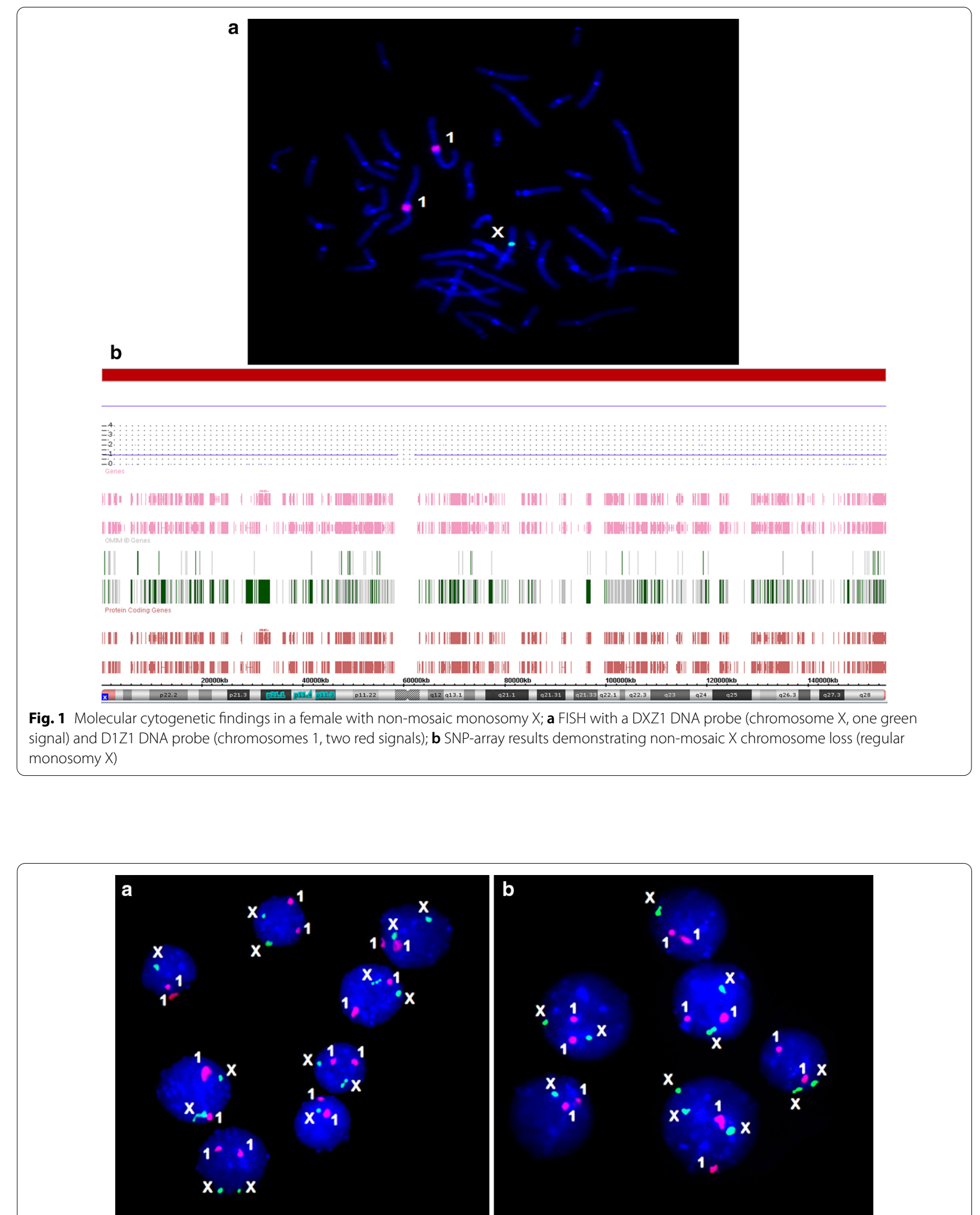

Fig. 2 Interphase FISH with DXZ1 and D1Z1 DNA probes (chromosome X/green signals and chromosomes 1/red signals, respectively); a case of monosomy/disomy mosaicism; b case of monosomy/disomy/trisomy mosaicism 
Table 1 Overview of TSM associated with supernumerary marker chromosomes

\begin{tabular}{|c|c|c|}
\hline Chromosome abnormality & Cell proportions (\%) & FISH results \\
\hline $45, X / 46, X,+m a r / 46, X X$ & $20 / 50 / 30$ & $\begin{array}{l}\text { 45,X.ishXp11.1q11.1(DXZ1 × 1)[10]/46,X, } \operatorname{mar}(X) \text {. ishXp11.1q11.1(DXZ1 ×2)[25] /46,XX. } \\
\text { ishXp11.1q11.1(DXZ1 × 2[15]; } \\
\text { nuc ishXcen }(D X Z 1 \times 1)[243] /(D X Z 1 \times 2)[757]\end{array}$ \\
\hline $45, X / 46, X,+\operatorname{mar}$ & $38 / 62$ & $\begin{array}{l}\text { 45,X.ishXp11.1q11.1(DXZ1 × 1)[19]/46,X,mar(X). ishXp1 1.1 q11.1(DXZ1×2)[31]; } \\
\text { nuc ishXcen(DXZ1 × 1)[341]/(DXZ1 ×2)[659] }\end{array}$ \\
\hline $45, X / 46, X,+$ mar & $54 / 46$ & $\begin{array}{l}\text { 45,X.ishXp1 1.1q11.1(DXZ1 × 1)[27]/46,X,mar(X). ishXp1 1.1 q11.1(DXZ1 ×2)[23]; } \\
\text { nuc ishXcen(DXZ1 × 1)[483]/(DXZ1 × 2)[517] }\end{array}$ \\
\hline $45, X / 46, X,+$ mar & $52 / 48$ & $\begin{array}{l}\text { 45,X.ishXp11.1q11.1(DXZ1 × 1)[26]/46,X,mar }(X) \text {. ishXp11.1 q11.1(DXZ1 × 2)[24]; } \\
\text { nuc ishXcen }(D X Z 1 \times 1)[448] /(D X Z 1 \times 2)[552]\end{array}$ \\
\hline $45, X / 47, X X,+$ mar/46,XX & $32 / 22 / 46$ & $\begin{array}{l}\text { 45,X.ishXp11.1q11.1 (pYAM10-40×1)[16]/47,XX,mar(X). ishXp11.1q11.1(DXZ1×3) } \\
{[11] / 46, X X . i s h X p 11.1 q 11.1(D X Z 1 \times 2)[23]} \\
\text { nuc ishXcen(DXZ1×1)[389]/(DXZ1 ×3)[311]/(DXZ1×2)[300] }\end{array}$ \\
\hline $45, X / 47, X X X / 46, X,+m a r^{*}$ & $38 / 42 / 20$ & 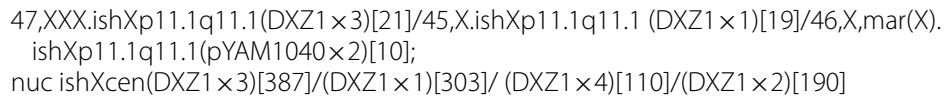 \\
\hline $45, \mathrm{X} / 46, \mathrm{X},+\mathrm{mar}$ & $72 / 28$ & $\begin{array}{l}\text { 45,X.ishXp11.1q11.1(DXZ1 × 1)[36]/46,X, } \operatorname{mar}(X) . i s h(D X Z 1 \times 2)[14] \\
\text { nuc ishXcen(DXZ1×1)[387]/(DXZ1 × 2)[613] }\end{array}$ \\
\hline $45, X / 46, X,+$ mar & $52 / 48$ & $\begin{array}{l}\text { 46,X, } \operatorname{mar}(X) . i s h X p 11.1 q 11.1(\mathrm{DXZ1} \times 2)[26] / 45, X . \operatorname{sishXp11.1q11.1~(DXZ1\times 1)[24];~} \\
\text { nuc ishXcen(DXZ1×1)[477]/(DXZ1 × 2)[523] }\end{array}$ \\
\hline $45, \mathrm{X} / 46, \mathrm{X},+\mathrm{mar}$ & $38 / 62$ & $\begin{array}{l}\text { 45,X.ishXp11.1q11.1(DXZ1 × 1)[19]/46,X,mar(X). ishXp11.1q11.1(DXZ1 ×2)[31]; } \\
\text { nuc ishXcen(DXZ1 × 1)[487]/(DXZ1 × 2)[513] }\end{array}$ \\
\hline $45, \mathrm{X} / 46, \mathrm{X},+$ mar & $48 / 52$ & $\begin{array}{l}\text { 46,X, } \operatorname{mar}(X) . i s h X p 11.1 q 11.1(\mathrm{DXZ1} \times 2)[21] / 45, X . \text { ishXp1 1.1q11.1 (DXZ1 × 1)[19]; } \\
\text { nuc ishXcen(DXZ1×1)[487]/(DXZ1 × 2)[513] }\end{array}$ \\
\hline $45, X / 46, X,+\operatorname{mar} / 46, X, i(X q) / 47, X X, i(X q)$ & $30 / 26 / 24 / 20$ & 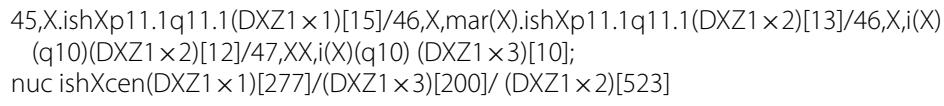 \\
\hline $45, X / 46, X$, mar & $26 / 74$ & $\begin{array}{l}\text { 45,X.ishXp11.1q11.1(DXZ1×1)[13]/46,XX.ishXp11.1q11.1(DXZ1×2)[37]; } \\
\text { nuc ishXcen(DXZ1 × 1)[209]/(DXZ1 × 2)[791] }\end{array}$ \\
\hline
\end{tabular}

* Cytogenetic analysis revealed cells with following karyotypes: 49,XXX,+mar,+mar; 48,XXX,+mar; 46,X,+mar; these karyotypes have not been detected by FISH

$\mathrm{X}$ chromosome-specific probes. Autosome and Y-chromosome-specific probes have been also applied. Complex supernumerary marker chromosomes and marker chromosomes derived from chromosomes other than chromosome $\mathrm{X}$ have not been detected.

Isochromosomes $\mathrm{iX}(\mathrm{q})$ (Fig. 3a) have been found in 12 cases $(0.3 \%)$. One case has been non-mosaic. All the remaining cases $(n=11)$ have demonstrated mosaicism. In 3 cases of mosaicism for $\mathrm{iX}(\mathrm{q})$, FISH analysis has revealed that isochromosomes are dicentric (Fig. 3b). Table 2 gives an overview of isochromosomes $\mathrm{X}$ detected in the present cohort.

Ring chromosomes (Fig. 4) have been revealed in 5 girls $(0.1 \%)$. All cases have been associated with chromosomal mosaicism. Table 3 provides an overview of ring chromosomes $\mathrm{X}$ that have been found in girls with neurodevelopmental disorders and congenital anomalies from the present cohort.

Clinically, all 111 girls with Turner's syndromeassociated karyotypes have demonstrated a range of neurodevelopmental phenotypes from minor neurobehavioral deficits to severe intellectual disability. Among other notable phenotypic features, we have observed short stature $(\mathrm{n}=96 ; 86.5 \%)$, abnormal sexual development $(\mathrm{n}=84 ; 75.7 \%)$, pterygium colli $(\mathrm{n}=83 ; 74.8 \%)$, cardiac anomalies $(\mathrm{n}=76 ; 68.5 \%)$ and renal abnormalities $(\mathrm{n}=10 ; 9 \%)$. Karyotype-phenotype correlations (i.e. correlations between mosaicism rates and phenotypic outcomes) have not been established.

\section{Discussion}

Turner's syndrome represents a common chromosomal (gonosomal) syndrome (newborn prevalence: 5.9/1000) [24]. So far, this is the sole syndrome associated with non-mosaic monosomy in human $[5,6]$. However, it is systematically hypothesized that liveborn children with non-mosaic 45, $\mathrm{X}$ karyotype are tissue-specific mosaics $[6,25,26]$. Recently, analyses of multiple tissues repeatedly supported this idea [27]. Since mosaicism is an important biomarker in Turner's syndrome, high attention is paid to mosaic cases. Moreover, studies of TSM in clinical cohorts are a broad area of medical genetic research. This may be explained by the fact that gonosomal mosaicism is a phenomenon with global relevance to biomedicine [28]. Mostly, these studies are performed for cohorts of patients with reproductive problems or 

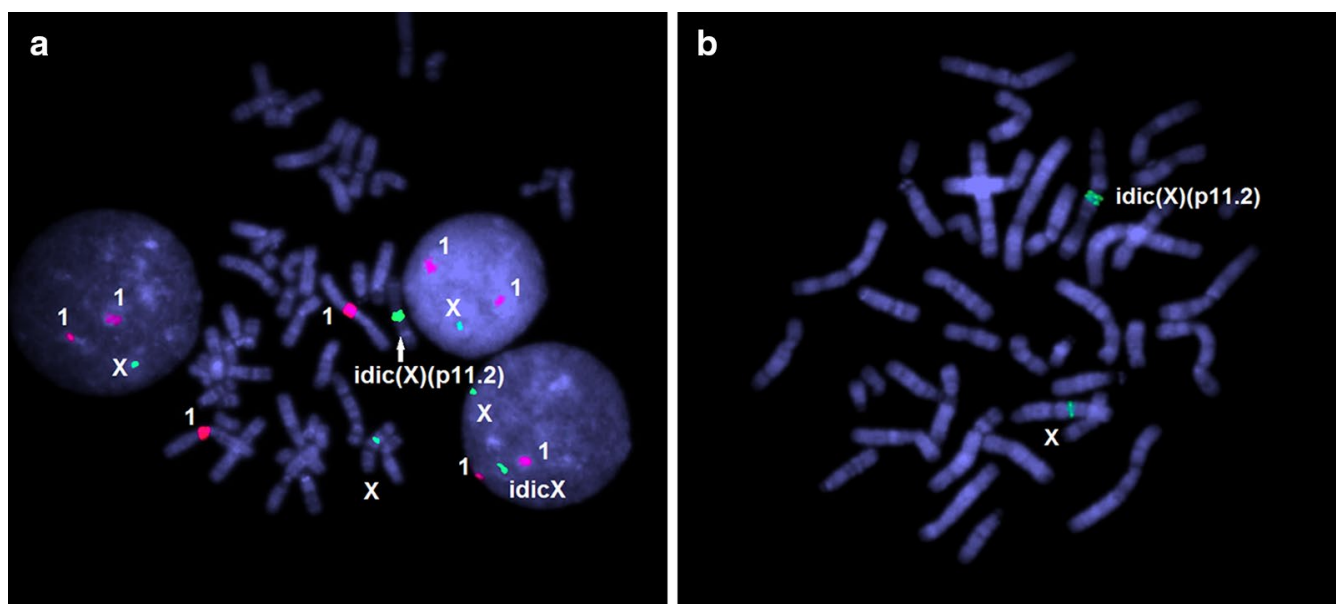

Fig. 3 FISH on metaphase plates of a girl with an isochromosome X; a FISH with DXZ1 and D1Z1 DNA probes (chromosome X/green signals and chromosomes 1/red signals, respectively); note X chromosome loss in two interphase nuclei (left and upper right) indicating this case to be mosaic; b one-color FISH with DXZ1 DNA probe demonstrating isochromosome to be dicentric

Table 2 Overview of TSM associated with isochromosomes

\begin{tabular}{|c|c|c|}
\hline Chromosome abnormality & Cell proportions & FISH results \\
\hline $45, X / 46, X, i(X q) / 46, X X$ & $60 / 30 / 10$ & $\begin{array}{l}\text { 45,X.ishXp11.1q11.1(DXZ1 × 1)[30]/46,X,i(X).ishXp11.1q11.1(DXZ1 ×2)[15]/46,XX. } \\
\text { ishXp11.1q11.1(DXZ1 × 2)[5]; } \\
\text { nuc ishXcen(DXZ1 × 1)[321]/(DXZ1 × 2)[679] }\end{array}$ \\
\hline $45, X / 46, X, i(X q) / 46, X X$ & $40 / 26 / 34$ & 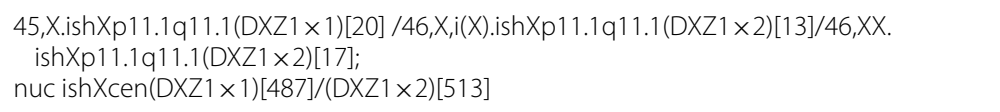 \\
\hline $45, X / 46, X, i(X q)$ & $32 / 68$ & $\begin{array}{l}\text { 46,X,i(X).ishXp1 1.1q11.1(DXZ1×2)[34]/45,X.ishXp1 1.1q11.1 (DXZ1×1)[16]; } \\
\text { nuc ishXcen }(\mathrm{DXZ1} \times 1)[389] /(\mathrm{DXZ1} \times 2)[211]\end{array}$ \\
\hline $45, X / 46, X, i(X q)$ & $74 / 26$ & $\begin{array}{l}\text { 45,X.ishXp11.1q11.1(DXZ1×1)[37]/46,X,i (X).ishXp11.1q11.1(DXZ1 ×2)[13]; } \\
\text { nuc ishXcen(DXZ1× 1)[717]/(DXZ1 × 2)[283] }\end{array}$ \\
\hline $45, X / 46, X, i(X q)$ & $44 / 56$ & $\begin{array}{l}\text { 46,X,i(X).ishXp1 1.1q11.1(DXZ1×2)[28]/45,X.ishXp11.1q11.1(DXZ1 × 1)[22]; } \\
\text { nuc ishXcen }(\mathrm{DXZ1} \times 1)[499] /(\mathrm{DXZ1} \times 2)[501]\end{array}$ \\
\hline $45, X / 46, X, i(X q)$ & $36 / 64$ & 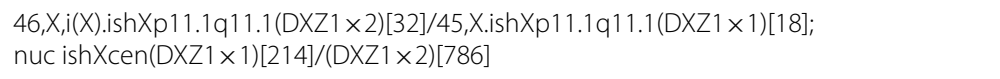 \\
\hline $45, X / 46, X, \operatorname{dic}(X)(q 22.2)$ & $24 / 76$ & $\begin{array}{l}\text { 46,X,idic }(X) \text {.ishXp11.1q11.1(DXZ1×3)[38]/45,X.ishXp11.1q11.1(DXZ1 × 1)[12]; } \\
\text { nuc ishXcen }(D X Z 1 \times 3)[613] /(D X Z 1 \times 1)[387]\end{array}$ \\
\hline $45, X / 46, X, i(X)(q 11.1)$ & $43 / 57$ & $\begin{array}{l}\text { 46,X,i(X). ishXp1 1.1q11.1(DXZ1×2)[17]/45,X.ishXp1 1.1q11.1(DXZ1×1)[13]; } \\
\text { nuc ishXcen }(\mathrm{DXZ1} \times 1)[413] /(\mathrm{DXZ1} \times 2)[587]\end{array}$ \\
\hline 45,X/46,X,idic(X)(p11.4)/ 46,XX & $34 / 52 / 14$ & $\begin{array}{l}\text { 46,X,idic (X).ishXp11.1q11.1(DXZ1×3)[26]/45,X.ishXp11.1q11.1(DXZ1×1)[17]/46,XX. } \\
\text { ishXp11.1q11.1(DXZ1 × 2)[7]; } \\
\text { nuc ishXcen(DXZ1× 1)[389]/(DXZ1×3)[300]/ (DXZ1×2)[211] }\end{array}$ \\
\hline 45,X/46,X,idic(X)(p11.3) & $32 / 68$ & $\begin{array}{l}\text { 46,X,idic(X).ishXp1 1.1q11.1(DXZ1 × 3)[34]/45,X.ishXp11.1q11.1(DXZ1 × 1)[16]; } \\
\text { nuc ishXcen }(\mathrm{DXZ1} \times 3)[623] /(\mathrm{DXZ1} \times 1)[377]\end{array}$ \\
\hline $45, X / 46, X,+\operatorname{mar} / 46, X, i(X q) / 47, X X, i(X q)$ & $30 / 26 / 24 / 20$ & 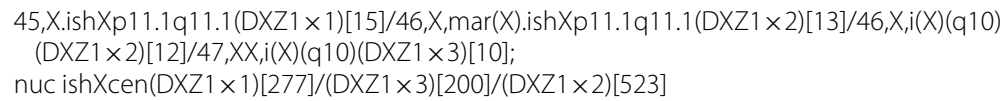 \\
\hline
\end{tabular}

for children without specific clinical features [8, 29-31]. Surprisingly, despite of the presence of neurobehavioral and psychiatric endophenotypes in the clinical picture of Turner's syndrome, analyses of TSM are exclusive in neurodevelopmental cohorts [32, 33]. The present study fills this gap providing a comprehensive analysis of TSM among females with neurodevelopmental disorders. Thus, this mosaicism type is involved in $1.9 \%$ of cases among neurodevelopmental disorders, i.e. such a phenotypically variable group of patients.

Somatic gonosomal mosaicism manifesting as aneuploidy is a contributor to the pathogenesis of numerous 

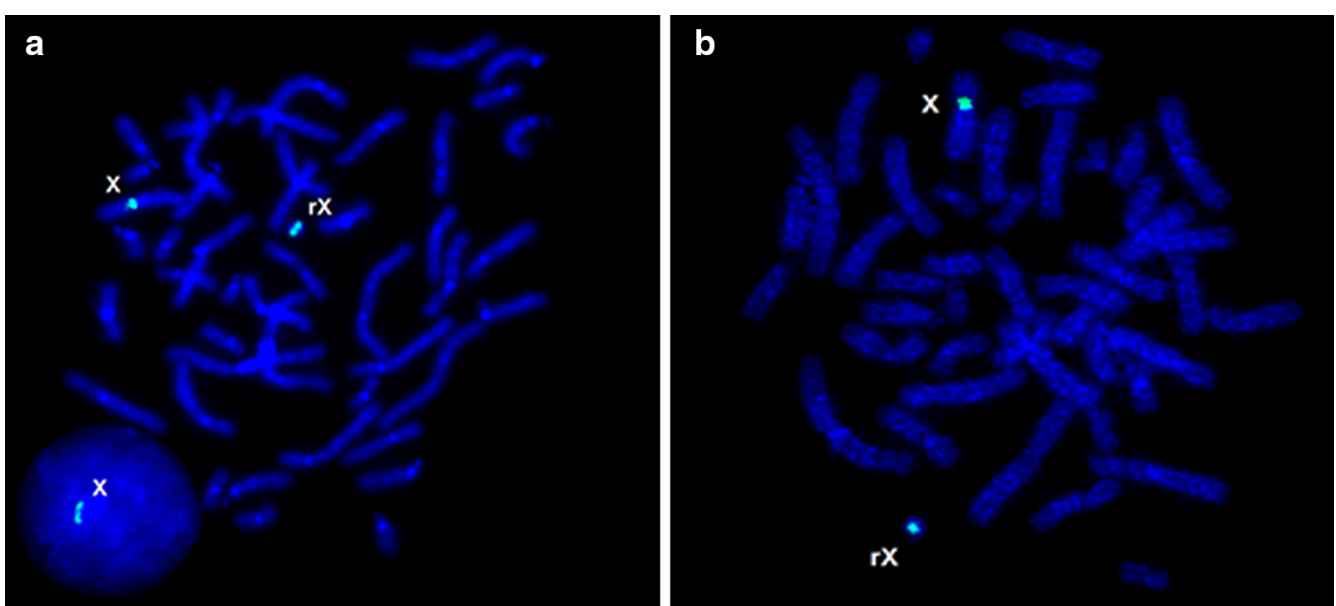

Fig. 4 FISH with a DXZ1 DNA probe on metaphase plates of two girls with ring chromosome X (a, $\mathbf{b})$; a note X chromosome loss in interphase nucleus indicating the case to be mosaic

Table 3 Overview of TSM associated with ring chromosomes

\begin{tabular}{|c|c|c|}
\hline Chromosome abnormality & Cell proportions & FISH results \\
\hline $45, X / 46, X, r(X) / 46, X X$ & $24 / 68 / 8$ & $\begin{array}{l}\text { 45,X.ishXp11.1q11.1(DXZ1 × 1)[12]/46,X,r(X).ishXp11.1q11.1(DXZ1×2) } \\
\text { [34]/46,XX. ishXp11.1q11.1(DXZ1×2)[4]; } \\
\text { nuc ishXcen }(\mathrm{DXZ1} \times 1)[209] /(\mathrm{DXZ1} \times 2)[791]\end{array}$ \\
\hline $45, X / 46, X, r(X)(p 21 q 21)$ & $43 / 57$ & 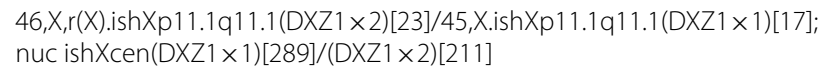 \\
\hline $45, X / 46, X, r(X)$ & $28 / 72$ & $\begin{array}{l}\text { 46,X,r(X).ishXp1 1.1q11.1(DXZ1 × 2)[36]/45,X.ishXp11.1q11.1(DXZ1 × 1)[14]; } \\
\text { nuc ishXcen(DXZ1 X 1)[389]/(DXZ1 × 2)[411] }\end{array}$ \\
\hline $45, X / 46, X, r(X)$ & $36 / 64$ & $\begin{array}{l}\text { 46,X,r }(X) . \text { ishXp1 1.1q11.1(DXZ1×2)[32]/45,X.ishXp11.1q11.1(DXZ1 × 1)[18]; } \\
\text { nuc ishXcen(DXZ1 × 1)[550]/(DXZ1 × 2)[450] }\end{array}$ \\
\hline $45, X / 46, X, r(X)$ & $42 / 58$ & $\begin{array}{l}\text { 46,X,r }(X) \text {.ishXp11.1q11.1(DXZ1×2)[29]/45,X.ishXp11.1q11.1(DXZ1 × 1)[21]; } \\
\text { nuc ishXcen(DXZ1 × 1)[489]/(DXZ1 × 2)[511] }\end{array}$ \\
\hline
\end{tabular}

diseases [7, 34-37]. Here, we have shown that $1.2 \%$ of females with neurodevelopmental disorders are affected by mosaic $\mathrm{X}$ chromosome loss alone. Therefore, one can suggest that mosaicism for monosomy of chromosome $\mathrm{X}$ is a highly probable and relatively common mechanism of brain diseases in females. Supernumerary marker chromosomes derived from gonosomes have extremely variable phenotypic outcomes from asymptomatic carriage to irritant medical problems $[38,39]$. Current report suggests that mosaicism for $\mathrm{X}$ chromosome loss and supernumerary marker chromosome $\mathrm{X}$ may be involved in pathogenesis of neurodevelopmental disorders in $0.3 \%$ of cases. TSM for X chromosome loss and isochromosomes $\mathrm{X}$ is suggested to have similar contribution to pathogenesis of neurodevelopmental disorders as TSM for supernumerary marker chromosomes X. TSM for X chromosome loss and ring chromosomes $\mathrm{X}$ is likely to contribute to pathogenesis of neurodevelopmental disorders in $0.1 \%$ of cases. The distribution of Turner's syndrome-associated karyotypes among 111 girls is close to the results of the most comprehensive studies dedicated to the analysis of karyotypic heterogeneity in females with Turner's syndrome $[5,6,8,10,11]$. However, according to the database of marker chromosomes managed by Prof. Thomas Liehr (http://cs-tl.de/DB/CA/sSMC/0Start.html), 465/715 of Turner syndrome cases with the marker chromosome are derived from chromosome $\mathrm{Y}$ and only 246/715 cases are derived from chromosome $\mathrm{X}$. The potential discrepancy between marker chromosome database and the data of our study may be related to the differences of cohorts addressed. Here, we address the cohort with relatively unspecific phenotypes (i.e. neurodevelopmental disorders and congenital anomalies), whereas marker chromosome database describes the distribution of derivative chromosomes among individuals with a specific phenotype (i.e. Turner's syndrome). Alternatively, a more-or-less universal explanation referred to as the particularity of the cohort may be given. The lack of karyotype-phenotype correlations may be explained by unequal intertissular distribution of abnormal cells, 
which has been systematically reported previously [6-11, $26,27]$.

It is import to note that somatic chromosome abnormalities (aneuploidy and structural rearrangements) are ontogenetically instable. In other words, the rates of mosaicism may increase with age mediating agingrelated diseases and adverse aging effects [23, 40-44]. More importantly, X chromosome loss progresses during aging and is considered as a cytogenetic biomarker of aging [45-47]. Therefore, it is highly likely that the amount of cells affected by $\mathrm{X}$ chromosome loss will increase during the lifespan of girls with TSM. In the neurodevelopmental context, it is important to mention the involvement of mosaic $\mathrm{X}$ chromosome monosomy in neuropsychiatric diseases. Thus, $\mathrm{X}$ chromosome loss is associated with a variety of neurobehavioral diseases in children, adolescents and adults including familial cases $[13,14,48,49]$. Schizophrenia and comorbid psychiatric disorders are commonly associated with $\mathrm{X}$ chromosome aneuploidy, which may specifically affect the brain [21, 50-52]. There are evidences for an involvement of agingrelated X chromosome loss in the pathogenesis of Alzheimer's disease [53-55]. In total, it is to conclude that $\mathrm{X}$ chromosome loss accumulated throughout ontogeny represents a mechanism for brain diseases with different ages of onset $[25,56]$. Additionally, X chromosome loss has been shown to be associated with numerous diseases characterized by female preponderance (e.g. autoimmune diseases), which we have reviewed recently [7]. Therefore, unapparent phenotypic manifestations of TSM [57], should not be considered as a limitation for defining TSM as a biomarker for multifactorial diseases mediated by $\mathrm{X}$ chromosome aneuploidy. Furthermore, aging-related exhausting of molecular pathways guaranteeing chromosome stability and genetic-environmental interactions predispose to an increase in genome instability levels throughout ontogeny [23, 34, 58-62]. Moreover, chromosome abnormalities may initiate chromosome instability per se [23]. These observations allowed us to propose a hypothesis described below.

\section{Hypothesis}

We hypothesize that levels of TSM are likely to increase in different tissues throughout the lifespan. Accordingly, this increase mediated by alterations to genome safeguarding pathways and genetic-environmental interactions would lead to occurrence of diseases associated with $\mathrm{X}$ chromosome loss. Among these diseases are neurobehavioral disorders, schizophrenia, dementia (e.g. Alzheimer's disease) and autoimmune diseases. Taking into account social importance of these diseases, one may be aware about the application of TSM analysis for early (preclinical) diagnosis, prognosis and possible therapeutic interventions. In this context, we propose molecular cytogenetic monitoring of TSM for early detection of the increase of $\mathrm{X}$ chromosome loss levels throughout the life of the affected females. Additionally, system biology analyses of molecular and cellular pathways leading to the increase of $\mathrm{X}$ chromosome loss levels may offer a possibility to control/inhibit chromosomal mosaicism/instability. The combination of molecular cytogenetic monitoring and systems biology analysis of females with TSM would eventually lead to a possibility of successful evidence-based therapies of devastating multifactorial diseases.

\section{Conclusions}

The incidence of Turner's syndrome-associated karyotypes in girls with neurodevelopmental disorders achieves $2.8 \%$ (i.e. $20-30$ in 1000 girls with intellectual disability, autism, epilepsy and/or congenital anomalies). It is to note that more than two-thirds of these girls exhibit TSM. Significant karyotypic heterogeneity mediated by TSM is observed in females with neurodevelopmental disorders. These data provide evidence for TSM contribution to the risk of brain diseases. Taking into account previous observations on somatic chromosomal mosaicism, we hypothesize that TSM proportions may ontogenetically change in favor of $\mathrm{X}$ chromosome loss. Thus, the occurrence of TSM might be a biomarker for adult-onset (multifactorial) diseases, which are mediated by $\mathrm{X}$ chromosome loss in an appreciable proportion of cases. Consequently, detecting and monitoring TSM is important for early diagnosis, prognosis and evidence-based therapeutic interventions in corresponding diseases.

\section{Author contributions}

SGV and IYI conceived the research, designed the study, got funding and wrote the manuscript; SGV, ADK, OSK, VSK and IYI analyzed the data; ADK, OSK, VSK and IAD performed cytogenetic analysis; SGV, ADK, IAD, IVS, YBY and IYI performed FISH analysis; OSK and IYI performed SNP array analysis; IVS and YBY contributed important reagents (DNA probes); SGV, YBY and IYI made important theoretical contributions. All authors have read and approved the final manuscript.

\section{Funding}

The reported study was partially funded by RFBR and CITMA according to the research project No. 18-515-34005. Prof. SG Vorsanova's lab is supported by the Government Assignment of the Russian Ministry of Health, Assignment No. AAAA-A18-1 18051590122-7. Prof. IY lourov's lab is supported by the Government Assignment of the Russian Ministry of Science and Higher Education, Assignment No. AAAA-A19-119040490101-6.

Availability of data and materials

The data of this study are all included in the article.

Ethics approval and consent to participate

Our study was approved by the Ethics Committee of the Veltischev Research and Clinical Institute for Pediatrics of the Pirogov Russian National Research 
Medical University, Ministry of Health of Russian Federation, Moscow. Written informed consent was obtained from all the parents of the participants.

\section{Consent for publication}

Not applicable.

\section{Competing interests}

The authors declare that they have no competing interests.

\section{Author details}

${ }^{1}$ Veltischev Research and Clinical Institute for Pediatrics of the Pirogov Russian National Research Medical University, Ministry of Health of Russian Federation, Moscow, Russia 125412. ${ }^{2}$ Yurov's Laboratory of Molecular Genetics and Cytogenomics of the Brain, Mental Health Research Center, Moscow, Russia 115522.

${ }^{3}$ Department of Medical Biological Disciplines, Belgorod State University, Belgorod, Russia 308015.

Received: 20 December 2020 Accepted: 14 January 2021 Published online: 11 February 2021

\section{References}

1. Shereshevsky NA. On the problem of multiple developmental anomalies and their relation of the endocrine gonads. Vestik Endokrinologii. 1925;1:295-301.

2. Turner HT. A syndrome of infantilism, congenital webbed neck, and cubitus valgus. Endocrinology. 1938;23:566-74.

3. Böhles H. Ullrich-Turner-Syndrom, 1929-1938. In: Böhles H, editor. Historische Fälle aus der Medizin. Berlin: Springer; 2020. p. 269-80.

4. Ford CE, Jones KW, Polani PE, De Almeida JC, Briggs JH. A sex-chromosome anomaly in a case of gonadal dysgenesis (Turner's syndrome). Lancet. 1959:1(7075):711-3.

5. Sybert VP, McCauley E. Turner's syndrome. N Engl J Med. 2004;351:1227-38.

6. Cui X, Cui Y, Shi L, Luan J, Zhou X, Han J. A basic understanding of Turne syndrome: incidence, complications, diagnosis, and treatment. Intractable Rare Dis Res. 2018:7(4):223-8.

7. lourov IY, Vorsanova SG, Yurov YB, Kutsev SI. Ontogenetic and pathogenetic views on somatic chromosomal mosaicism. Genes (Basel). 2019;10(5):379.

8. Jacobs P, Dalton P, James R, Mosse K, Power M, Robinson D, Skuse D. Turner syndrome: a cytogenetic and molecular study. Ann Hum Genet. 1997:61(Pt 6):471-83.

9. Homer L, Le Martelot MT, Morel F, Amice V, Kerlan V, Collet M, De Braekeleer M. 45, X/46, XX mosaicism below 30\% of aneuploidy: clinical implications in adult women from a reproductive medicine unit. Eur J Endocrinol. 2010;162(3):617-23.

10. Wolff DJ, Van Dyke DL, Powell CM. Working group of the ACMG Laboratory Quality Assurance Committee. Laboratory guideline for turner syndrome. Genet Med. 2010;12(1):52-5.

11. Levitsky LL, Luria AH, Hayes FJ, Lin AE. Turner syndrome: update on biology and management across the life span. Curr Opin Endocrinol Diabetes Obes. 2015;22(1):65-72.

12. Vorsanova SG, lourov IY, Beresheva AK, Demidova IA, Monakhov W, Kravets VS, Bartseva OB, Goyko EA, Soloviev IV, Yurov YB. Non-disjunction of chromosome 21, alphoid DNA variation, and sociogenetic features of down syndrome. Tsitol Genet. 2005;39(6):30-6.

13. Vorsanova SG, Yurov IY, Demidova IA, Voinova-Ulas VY, Kravets VS, Solov'ev IV, Gorbachevskaya NL, Yurov YB. Variability in the heterochromatin regions of the chromosomes and chromosomal anomalies in children with autism: identification of genetic markers of autistic spectrum disorders. Neurosci Behav Physiol. 2007;37(6):553-8.

14. Vorsanova SG, Voinova VY, Yurov IY, Kurinnaya OS, Demidova IA, Yurov YB. Cytogenetic, molecular-cytogenetic, and clinical-genealogical studies of the mothers of children with autism: a search for familial genetic markers for autistic disorders. Neurosci Behav Physiol. 2010;40(7):745-56.

15. McGowan-Jordan J, Simons A, Schmid M. ISCN 2016: an international system for human cytogenomic nomenclature. Basel: Karger; 2016.

16. Yurov YB, Soloviev IV, Vorsanova SG, Marcais B, Roizes G, Lewis R. High resolution multicolor fluorescence in situ hybridization using cyanine and fluorescein dyes: rapid chromosome identification by directly fluorescently labeled alphoid DNA probes. Hum Genet. 1996;97(3):390-8.

17. Vorsanova SG, Yurov YB, Kolotii AD, Soloviev IV. FISH analysis of replication and transcription of chromosome $X$ loci: new approach for genetic analysis of Rett syndrome. Brain Dev. 2001;23(Suppl 1):S191-5.

18. Yurov YB, Vorsanova SG, lourov IY, Demidova IA, Beresheva AK, Kravetz VS, Monakhov V, Kolotii AD, Voinova-Ulas VY, Gorbachevskaya NL. Unexplained autism is frequently associated with low-level mosaic aneuploidy. J Med Genet. 2007:44(8):521-5.

19. Iourov IY. Quantitative fluorescence in situ hybridization (QFISH). Methods Mol Biol. 2017;1541:143-9.

20. Yurov YB, Vorsanova SG, Soloviev IV, Ratnikov AM, lourov IY. FISH-based assays for detecting genomic (chromosomal) mosaicism in human brain cells. Neuromethods. 2017:131:27-41.

21. Yurov YB, Vorsanova SG, Demidova IA, Kolotii AD, Soloviev IV, lourov IY. Mosaic brain aneuploidy in mental illnesses: an association of low-level post-zygotic aneuploidy with schizophrenia and comorbid psychiatric disorders. Curr Genomics. 2018;19(3):163-72.

22. Iourov IY, Vorsanova SG, Zelenova MA, Vasin KS, Kurinnaia OS, Korostelev SA, Yurov YB. Epigenomic variations manifesting as a loss of heterozygosity affecting imprinted genes represent a molecular mechanism of autism spectrum disorders and intellectual disability in children. Zh Nevrol Psikhiatr Im S S Korsakova. 2019:119(5):91-7.

23. Iourov IY, Vorsanova SG, Yurov YB, Zelenova MA, Kurinnaia OS, Vasin KS, Kutsev SI. The cytogenomic "theory of everything": chromohelkosis may underlie chromosomal instability and mosaicism in disease and aging. Int J Mol Sci. 2020;21(21):8328.

24. Berglund A, Stochholm K, Gravholt CH. The epidemiology of sex chromosome abnormalities. Am J Med Genet C Semin Med Genet. 2020;184(2):202-15

25. Iourov IY, Vorsanova SG, Yurov YB. Chromosomal variation in mammalian neuronal cells: known facts and attractive hypotheses. Int Rev Cytol. 2006:249:143-91.

26. Araújo A, Ramos ES. Cryptic mosaicism involving a second chromosome $X$ in patients with Turner syndrome. Braz J Med Biol Res. 2008:41(5):368-72

27. Graff A, Donadille B, Morel H, Villy MC, Bourcigaux N, Vatier C, Borgel A, Khodawardi A, Siffroi JP, Christin-Maitre S. Added value of buccal cell FISH analysis in the diagnosis and management of Turner syndrome. Hum Reprod. 2020;35(10):2391-8.

28. Iourov IY, Vorsanova SG, Yurov YB. Chromosomal mosaicism goes global. Mol Cytogenet. 2008;1:26

29. Tosson H, Rose SR, Gartner LA. Description of children with $45, X / 46, X Y$ karyotype. Eur J Pediatr. 2012;171(3):521-9.

30. Lindhardt Johansen $M$, Hagen CP, Rajpert-De Meyts E, Kjærgaard S, Petersen BL, Skakkebæk NE, Main KM, Juul A. 45,X/46,XY mosaicism: phenotypic characteristics, growth, and reproductive function-a retrospective longitudinal study. J Clin Endocrinol Metab. 2012;97(8):E1540-9.

31. Wu Q, Wang $C$, Shi H, Kong $X$, Ren $S$, Jiang M. The clinical manifestation and genetic evaluation in patients with $45, X / 46, X Y$ mosaicism. Sex Dev. 2017:11(2):64-9.

32. Ross J, Zinn A, McCauley E. Neurodevelopmental and psychosocial aspects of Turner syndrome. Ment Retard Dev Disabil Res Rev. 2000;6(2):135-41.

33. Hutaff-Lee C, Bennett E, Howell S, Tartaglia N. Clinical developmental, neuropsychological, and social-emotional features of Turner syndrome. Am J Med Genet C Semin Med Genet. 2019:181(1):126-34.

34. Iourov IY, Vorsanova SG, Yurov YB. Somatic cell genomics of brain disorders: a new opportunity to clarify genetic-environmental interactions. Cytogenet Genome Res. 2013;139(3):181-8.

35. Hultén MA, Jonasson J, Iwarsson E, Uppal P, Vorsanova SG, Yurov YB, lourov IY. Trisomy 21 mosaicism: we may all have a touch of down syndrome. Cytogenet Genome Res. 2013;139(3):189-92.

36. Vorsanova SG, Zelenova MA, Yurov YB, lourov IY. Behavioral variability and somatic mosaicism: a cytogenomic hypothesis. Curr Genomics. 2018;19(3):158-62.

37. Vorsanova SG, Yurov YB, lourov IY. Dynamic nature of somatic chromosomal mosaicism, genetic-environmental interactions and therapeutic opportunities in disease and aging. Mol Cytogenet. 2020;13:16.

38. Liehr T, Mrasek K, Hinreiner S, Reich D, Ewers E, Bartels I, Seidel J, Emmanuil N, Petesen M, Polityko A, Dufke A, lourov I, Trifonov V, 
Vermeesch J, Weise A. Small supernumerary marker chromosomes (SSMC) in patients with a 45,X/46,X,+mar karyotype - 17 new cases and a review of the literature. Sex Dev. 2007;1(6):353-62.

39. Liehr T, Al-Rikabi A. Mosaicism: reason for normal phenotypes in carriers of small supernumerary marker chromosomes with known adverse outcome. A systematic review. Front Genet. 2019;10:1131.

40. Yurov YB, Vorsanova SG, lourov IY. GIN'n'CIN hypothesis of brain aging: deciphering the role of somatic genetic instabilities and neural aneuploidy during ontogeny. Mol Cytogenet. 2009;2:23.

41. Yurov YB, Vorsanova SG, lourov IY. Ontogenetic variation of the human genome. Curr Genom. 2010;11(6):420-5.

42. Kennedy SR, Loeb LA, Herr AJ. Somatic mutations in aging, cancer and neurodegeneration. Mech Ageing Dev. 2012;133(4):118-26.

43. Vijg J. Somatic mutations, genome mosaicism, cancer and aging. Curr Opin Genet Dev. 2014;26:141-9.

44. Potter H, Chial HJ, Caneus J, Elos M, Elder N, Borysov S, Granic A. Chromosome instability and mosaic aneuploidy in neurodegenerative and neurodevelopmental disorders. Front Genet. 2019;10:1092.

45. Guttenbach M, Koschorz B, Bernthaler U, Grimm T, Schmid M. Sex chromosome loss and aging: in situ hybridization studies on human interphase nuclei. Am J Hum Genet. 1995;57(5):1143-50.

46. Stone JF, Sandberg AA. Sex chromosome aneuploidy and aging. Mutat Res. 1995;338(1-6):107-13.

47. Russell LM, Strike P, Browne CE, Jacobs PA. X chromosome loss and ageing. Cytogenet Genome Res. 2007;116(3):181-5.

48. Vorsanova SG, lurov L, Kurinnaia OS, Voinova V, lurov I. Genomic abnormalities in children with mental retardation and autism: the use of comparative genomic hybridization in situ (HRCGH) and molecular karyotyping with DNA-microchips (array CGH). Zh Nevrol Psikhiatr Im S S Korsakova. 2013;113(8):46-9.

49. Printzlau F, Wolstencroft J, Skuse DH. Cognitive, behavioral, and neural consequences of sex chromosome aneuploidy. J Neurosci Res. 2017:95(1-2):311-9.

50. Yurov YB, Vostrikov VM, Vorsanova SG, Monakhov WV, lourov IY. Multicolor fluorescent in situ hybridization on post-mortem brain in schizophrenia as an approach for identification of low-level chromosomal aneuploidy in neuropsychiatric diseases. Brain Dev. 2001;23(Suppl 1):S186-90.

51. Demirhan O, Taştemir D. Chromosome aberrations in a schizophrenia population. Schizophr Res. 2003;65(1):1-7.
52. Yurov YB, Vorsanova SG, Demidova IA, Kravets VS, Vostrikov VM, Soloviev IV, Uranova NA, lourov IY. Genomic instability in the brain: chromosomal mosaicism in schizophrenia. Zh Nevrol Psikhiatr Im S S Korsakova. 2016;116(11):86-91.

53. Yurov YB, Vorsanova SG, Liehr T, Kolotii AD, lourov IY. X chromosome aneuploidy in the Alzheimer's disease brain. Mol Cytogenet. 2014;7(1):20.

54. Graham EJ, Vermeulen M, Vardarajan B, Bennett D, De Jager P, Pearse RV 2nd, Young-Pearse TL, Mostafavi S. Somatic mosaicism of sex chromosomes in the blood and brain. Brain Res. 2019;1721:146345.

55. Bajic VP, Essack M, Zivkovic L, Stewart A, Zafirovic S, Bajic VB, Gojobori T, Isenovic E, Spremo-Potparevic B. The X files: "The mystery of X chromosome instability in Alzheimer's disease." Front Genet. 2020;10:1368.

56. Iourov IY, Vorsanova SG, Yurov YB. Single cell genomics of the brain: focus on neuronal diversity and neuropsychiatric diseases. Curr Genom. 2012;13(6):477-88.

57. Tuke MA, Ruth KS, Wood AR, Beaumont RN, Tyrrell J, Jones SE, Yaghootkar H, Turner CLS, Donohoe ME, Brooke AM, Collinson MN, Freathy RM, Weedon MN, Frayling TM, Murray A. Mosaic Turner syndrome shows reduced penetrance in an adult population study. Genet Med. 2019:21(4):877-86.

58. lourov IY, Vorsanova SG, Zelenova MA, Korostelev SA, Yurov YB. Genomic copy number variation affecting genes involved in the cell cycle pathway: implications for somatic mosaicism. Int J Genom. 2015;2015:757680.

59. Ye CJ, Sharpe Z, Alemara S, Mackenzie S, Liu G, Abdallah B, Horne S, Regan S, Heng HH. Micronuclei and genome chaos: changing the system inheritance. Genes (Basel). 2019;10(5):366.

60. Iourov IY, Vorsanova SG, Yurov YB. The variome concept: focus on CNVariome. Mol Cytogenet. 2019;12:52.

61. Melo Pereira S, Ribeiro R, Logarinho E. Approaches towards longevity: reprogramming, senolysis, and improved mitotic competence as antiaging therapies. Int J Mol Sci. 2019;20(4):938.

62. Verma N, Franchitto M, Zonfrilli A, Cialfi S, Palermo R, Talora C. DNA damage stress: Cui prodest? Int J Mol Sci. 2019;20(5):1073.

\section{Publisher's Note}

Springer Nature remains neutral with regard to jurisdictional claims in published maps and institutional affiliations.
Ready to submit your research? Choose BMC and benefit from:

- fast, convenient online submission

- thorough peer review by experienced researchers in your field

- rapid publication on acceptance

- support for research data, including large and complex data types

- gold Open Access which fosters wider collaboration and increased citations

- maximum visibility for your research: over 100M website views per year

At $B M C$, research is always in progress.

Learn more biomedcentral.com/submissions 